PENELITIAN

\title{
Pengaruh Pemberian Minuman Karbohidrat Dan Protein Whey Pra Operasi Terhadap Kadar $C$ - Reactive Protein Pasca Operasi Pada Pasien Mastektomi
}

\section{Effect Of Oral Preoperative Carbohydrate And Whey Protein On Level Of C-Reactive Protein On Post operative Mastektomi}

\author{
Erwin Santoso Andreanto $\bigotimes^{*}$, Aria Dian Primatika*, Jati Listiyanto Pujo* \\ *Bagian Anestesi dan Terapi Intensif FK UNDIP/ RSUP Dr. Kariadi \\ $\triangle$ Korespondesi/Correspondence: esandreanto@gmail.com
}

\begin{abstract}
Background: CRP is an acute phase protein levels in the blood are intimately associated with the acute inflammatory response that occurs. Surgery and prolonged fasting causes release of pro inflammatory cytokines and acute phase inflammatory mediators through a complex process

Objective: To prove that preoperative carbohydrate and whey protein drinks effects the postoperative CRP levels in mastectomy patients

Methods: It is a randomized controlled trial study. 26 samples are divided into two groups. The treatment group (13 samples) was given $400 \mathrm{~mL}$ of carbohydrate and whey protein drinks the night before surgery and $200 \mathrm{~mL} 4$ hours before surgery. The control group was given mineral water with the same amount and timing as the treatment group. Both groups were examined pre-and postoperative CRP levels.

Results: There were significant differences $(p=0.001)$ in postoperative CRP levels between the control group $(7,62 \pm 2,074)$ compared to postoperative CRP in treatment group $(2,81 \pm 2,920)$. There is also a significant difference $(p=0.000)$ in the difference between preoperative and postoperative CRP levels in the control group $(5,36 \pm 0,53)$ compared to the treatment group $C R P(0,89 \pm 0,938)$.

Conclusion: Preoperative carbohydrate and whey protein drinks loading has been prooved to reduce postoperative acute phase inflammatory response, which explains the increase of lower postoperative CRP levels in the treatment group compared to postoperative CRP levels in control group.
\end{abstract}

Keywords: CRP, acute inflammatory response, carbohydrate and whey protein drinks loading

ABSTRAK

Latar belakang : CRP adalah protein fase akut yang kadarnya dalam darah sangat 
berkaitan erat dengan respon inflamasi akut yang terjadi.Tindakanpembedahan dan puasa yang berkepanjangan menyebabkan pelepasan sitokin-sitokin proinflamasi dan mediator inflamasifaseakut melalui proses yang rumit.

Tujuan : Membuktikan pengaruh pemberian minuman karbohidrat dan protein whey praoperasi terhadap kadar CRP pascaoperasi pada pasien mastektomi.

Metode : Penelitian jenis uji klinis acak terkontrol. Sampel penelitian sebanyak 26 dibagi menjadi 2 kelompok. Kelompok perlakuan (13 sampel) diberikan $400 \mathrm{~mL}$ minuman karbohidrat dan protein whey malam sebelum operasi dan $200 \mathrm{~mL} 4$ jam sebelum operasi. Kelompok kontrol diberikan air mineral dengan jumlah dan waktu pemberian yang sama dengan kelompok perlakuan. Kedua kelompok diperiksa kadar CRP pra dan pascaoperasi.

Hasil : Terdapat perbedaan bermakna ( $p=0,001)$ pada kadarCRP pascaoperasi antara kelompok kontrol yaitu 7,62 \pm 2,074 dibandingkan dengan CRP pascaoperasi kelompok perlakuan yaitu 2,81 $\pm 2,920$. Selain itu juga terdapat perbedaan yang bermakna ( $p=$ 0,000) dalam selisih kadar CRP praoperasi dan pascaoperasi pada kelompok kontrol yaitu 5,36 \pm 0,535 dibandingkan dengan kelompok perlakuan yaitu 0,89 \pm 0,938.

Kesimpulan : Pemberian minuman karbohidrat dan protein whey pra operasi terbukti menurunkan respon inflamasi fase akut pascaoperasi, yang tergambar dari peningkatan kadar CRP pascaoperasi yang lebih rendah pada kelompok perlakuan dibandingkan dengan kelompok kontrol.

Kata kunci :CRP, respon inflamasi akut, pemberian minuman karbohidrat dan protein

\section{PENDAHULUAN}

Puasa selama 1 malam telah rutin dilakukan sebelum operasi elektif selama abad terakhir. Beberapa studi telah menunjukkan bahwa jika puasa semalam diubah menjadi pemberian karbohidrat pra-operasi, beberapa manfaat lebih lanjut dapat diperoleh. Juga ada temuan bahwa perlakuan ini (atau infus glukosa 30\% yang diberikan pada tingkat yang cukup tinggi) menghasilkan resistensi insulin yang secara substansial lebih rendah pasca operasi. Hal ini penting, karena resistensi insulin adalah mekanisme yang mendasari hiperglikemia, yang telah terbukti merugikan pasien pasca operasi. $^{1,2}$ Minuman karbohidrat pra operasi juga dapat memperbaiki kondisi umum pasca operasi dengan cara mencegah gangguan yang diakibatkan trauma pada metabolisme glukosa.,

Cedera jaringan akan menyebabkan terjadinya perubahanperubahan akibat rangsangan sitokin. 
Hal ini disebut sebagai respon fase akut. $^{5}$ Salah satu gambarannya adalah adanya produksi protein-protein fase akut di hepar. Protein- protein ini bertindak sebagai mediator inflamasi, anti proteinase dan scavenger pada perbaikan jaringan. Protein tersebut termasuk di antaranya adalah $C$ - reactive protein $(C R P){ }^{6-8}$

Untuk memungkinkan pemberian karbohidrat oral dalam jumlah besar, maka dibuatlah minuman kaya karbohidrat yang mengandung 12,5\% karbohidrat terutama berbentuk maltodekstrin, dengan osmolalitas rendah untuk memastikan pengosongan lambung yang cepat. ${ }^{1,9}$ Pasien yang diberi karbohidrat pra operasi memiliki produksi glukosa endogen rendah dan glucose uptake yang lebih baik. Kedua faktor inilah yang akan bertindak melawan stres akibat hiperglikemia. ${ }^{1,9}$ Pemberian karbohidrat oral pre operasi juga memperbaiki food intake, menjaga fungsi saluran cerna dan mengurangi respon katabolik. ${ }^{9,10}$

Penelitian ini bertujuan untuk pengaruh pemberian minuman karbohidrat dan protein whey pra operasi terhadap kadar $C$ - reactive protein pasca operasi pada pasien yang menjalani mastektomi.

\section{METODE}

Penelitian ini termasuk jenis uji klinis acak terkontrol dengan tujuan mengetahui pengaruh pemberian minuman karbohidrat dan protein whey pra operasi terhadap kadar CRP pasca operasi pada pasien mastektomi.

Subjek penelitian masuk kriteria inklusi yang akan menjalani operasi mastektomi elektif diberikan edukasi dan informed consent tentang penelitian yang akan dilakukan. Jika pasien setuju maka akan dilanjutkan dengan pengambilan sampel darah pertama sehari sebelum operasi. Pasien akan dibedakan menjadi kelompok kontrol dan kelompok perlakuan. Pada kelompok perlakuan diberikan minuman karbohidrat $400 \mathrm{ml}$ pada saat malam sebelum operasi dan $400 \mathrm{ml} 4$ jam sebelum operasi. Induksi anestesi menggunakan propofol, pelumpuh otot rokuronium, analgetik ketorolak dan tramadol, pemeliharaan dengan $\mathrm{O}_{2}$, isofluran dan $\mathrm{N}_{2} \mathrm{O}$ bila diperlukan. Sampel darah kedua diambil pada jam ke-6 setelah dimulai insisi pembedahan untukpemeriksaan kadar C-reactive protein. Sampel darah dikirimkan ke laboratorium untuk diperiksa kadar $C$-reactive protein. Dan seluruh data dikumpulkan dan dicatat untuk dianalisis statistik. 
Karbohidrat dan protein whey pra operasi adalah minuman yang mengandung karbohidrat dan protein whey (peptamen dengan kandungan maltodextrin dan sukrosa 58,1 gr/100 gr, protein whey $18,6 \mathrm{gr} / 100 \mathrm{gr}$, mct $18,6 \mathrm{gr} / 100 \mathrm{gr}$, traceelemen dan multivitamin) dengan kandungan 100 $\mathrm{kkal} / 100 \mathrm{ml}$ yang diberikan sebanyak $400 \mathrm{ml}$ pada malam sebelum operasi dan $200 \mathrm{ml} 4$ jam menjelang operasi.

\section{HASIL}

Sebanyak 26 pasien yang menjalani mastektomi masuk dalam kriteria inklusi dalam sampel penelitian. Pasien berkenan dimasukan dalam penelitian dan menandatangani informed concent. Selanjutnya pasien dikelompokkan dalam kelompok perlakuan (B) sebanyak 13 pasien dan kontrol (A) sebanyak 13 pasien.

Sebanyak 2 sampel dieksklusi. Satu sampel dari kelompok kontrol (A) karena operasi yang dilakukan ternyata tidak seperti yang diharapkan yaitu incisi biopsi tanpa dilanjutkan radikal mastektomi, dan satu sampel dari kelompok perlakuan (B) akibat dari prolong puasa karena operasi yang tertunda 2 jam. Dengan demikian, sampel penelitian ini adalah sebanyak 12 pasien dari kelompok A dan 12 pasien dari kelompok B.

Rerata usia untuk kelompok kontrol adalah 45,08 \pm 7,669 dan untuk kelompok perlakuan 43,25 $\pm 6,032(\mathrm{p}=$ 0,522). Hal ini menunjukkan bahwa usia subjek penelitian diantara kedua kelompok tidak berbeda bermakna. Rerata Body Mass Index (BMI) untuk kelompok kontrol adalah 23,20 $\pm 0,894$ dan untuk kelompok perlakuan 22,16 \pm $0,699(p=0,004)$. Lama operasi untuk kedua kelompok tidak berbeda bermakna, yaitu pada kelompok kontrol 162,50 $\pm 29,886$ menit dan kelompok perlakuan 165,83 $\pm 35,280$ menit dengan $\mathrm{p}=$ 0,805 (Tabel 6). Rerata jumlah perdarahan kelompok kontrol adalah 379,58 \pm 76,884 dan kelompok perlakuan adalah $371,67 \pm 73,957$ dengan $p=0,800$. Pada kelompok kontrol didapatkan masingmasing 6 sampel (50\%) yang sudah maupun belum menjalani kemoterapi sebelumnya, sedang pada kelompok perlakuan didapat 7 sampel ( $58,3 \%)$ yang sudah menjalani kemoterapi dan 5 sampel ( $41,7 \%$ ) yang belum. Kedua kelompok dapat dikatakan homogen.

Tabel 2 memperlihatkan data $C R P$ pra operasi dan pasca operasi dari kelompok kontrol dan kelompok perlakuan. Dapat dilihat bahwa tidak 
Tabel 1. Karakteristik Data

\begin{tabular}{|l|l|l|l|}
\hline Kelompok & $\begin{array}{l}\text { Kontrol } \\
\text { Mean } \pm \text { SD / Frek. (\%) }\end{array}$ & $\begin{array}{l}\text { Perlakuan } \\
\text { Mean } \pm \text { SD / Frek. (\%) }\end{array}$ & p \\
\hline Umur & $45,08 \pm 7,669$ & $43,25 \pm 6,032$ & $0,522^{\ddagger}$ \\
\hline BMI & $23,20 \pm 0,894$ & $22,16 \pm 0,699$ & $\begin{array}{l}0,004^{*} \\
¥\end{array}$ \\
\hline Riw. Kemoterapi & & & \\
\hline+ & $6(50)$ & $7(58,3)$ & $0,682^{\mathfrak{f}}$ \\
\hline- & $6(50)$ & $5(41,7)$ & \\
\hline Perdarahan & $379,58 \pm 76,884$ & $371,67 \pm 73,957$ & $0,800^{\ddagger}$ \\
\hline Lama operasi & $162,50 \pm 29,886$ & $165,83 \pm 35,280$ & $0,805^{¥}$ \\
\hline
\end{tabular}

Keterangan :

* Signifikan $\mathrm{p}<0,05$

${ }^{¥}$ Independent $t$ test

${ }^{£}$ Chi square test

Tabel 2. Data CRP pra dan pasca operasi pada kelompok kontrol dan perlakuan

\begin{tabular}{|l|l|l|l|}
\hline Kelompok & Kontrol & Perlakuan & $\begin{array}{l}\text { p } \\
\text { (uji beda tidak } \\
\text { berpasangan) }\end{array}$ \\
\hline$C R P$ pra ops & $2,27 \pm 1,680$ & $1,92 \pm 1,995$ & $0,478^{\epsilon}$ \\
\hline$C R P$ pasca ops & $7,62 \pm 2,074$ & $2,81 \pm 2,920$ & $0,001 * \epsilon$ \\
\hline $\begin{array}{l}\text { P } \\
\text { (uji beda berpasangan) }\end{array}$ & $0,002 * \S$ & $0,002 * \S$ & \\
\hline
\end{tabular}

Keterangan :

* Signifikan $\mathrm{p}<0,05$

${ }^{€}$ Mann Whitney test

$\S$ Wilcoxon test

Tabel 3. Data selisih $C R P$ pra operasi dan pasca operasi berdasarkan kelompok kontrol dan perlakuan

\begin{tabular}{|l|l|l|}
\hline Kelompok & Mean \pm SD & p \\
\hline Kontrol & $5,36 \pm 0,535$ & \multirow{2}{*}{$0,000^{*}$} \\
\cline { 1 - 2 } Perlakuan & $0,89 \pm 0,938$ & \\
\hline
\end{tabular}

Keterangan :

* Signifikan $p<0,05$

${ }^{€}$ Mann Whitney test 
didapatkan perbedaan bermakna ( $\mathrm{p}=$ 0,478) antara $C R P$ pra operasi kelompok kontrol yaitu $2,27 \pm 1,680$ dibandingkan dengan $C R P$ pra operasi kelompok perlakuan yaitu 1,92 $\pm 1,995$. Sebaliknya,terdapat perbedaan bermakna $(\mathrm{p}=0,001)$ pada $C R P$ pasca operasi antara kelompok kontrol yaitu 7,62 \pm 2,074 dibandingkan dengan CRP pasca operasi kelompok perlakuan yaitu 2,81 $\pm 2,920$. Selain itu, dapat juga kita lihat bahwa terdapat peningkatan yang bermakna $(\mathrm{p}=0,002)$ antara $C R P$ pra operasi pada kelompok kontrol yaitu 2,27 $\pm 1,680$ dibandingkan $C R P$ pasca operasi pada kelompok kontrol yaitu $7,62 \pm 2,074$. Begitu juga dapat kita lihat bahwa terdapat peningkatan bermakna ( $\mathrm{p}=0,002$ ) antara $C R P$ pra operasi pada kelompok perlakuan yaitu 1,92 $\pm 1,995$ dibandingkan dengan $C R P$ pasca operasi pada kelompok perlakuan yaitu $2,81 \pm 2,920$.

\section{PEMBAHASAN}

$C R P$ adalah protein fase akut yang kadarnya dalam darah sangat berkaitan erat dengan intensitas inflamasi yang terjadi dan dapat digunakan untuk memprediksi komplikasi pasca operasi. ${ }^{11}$ Tindakan pembedahan dan puasa yang berkepanjan- gan menyebabkan pelepasan sitokinsitokin proinflamasi dan juga dapat meningkatkan pelepasan mediator inflamasi fase akut setelah tindakan pembedahan. ${ }^{1-4}$ Kadar CRP mulai meningkat di plasma dalam waktu 4-6 jam setelah insisi, dimana nilai puncak terjadi dalam waktu 6 jam setelah insisi dan akan bertahan selama 24 - 48 jam pasca operasi. Pengambilan sampel darah untuk pemeriksaan $C R P$ pada penelitian ini dilakukan 6 jam setelah dimulai insisi pembedahan, diharapkan kadar CRP sudah mencapai puncak pada waktu tersebut.

Pemberian minuman karbohidrat dan protein whey pada penelitian ini menyebabkan periode puasa yang lebih singkat dan mengurangi respon inflamasi akut yang terjadi. Penelitian yang dilakukan Perrone et al (2011) menyatakan bahwa pengurangan periode puasa dengan pemberian karbohidrat oral dan protein whey aman dan mengurangi resistensi insulin dan respon fase akut pasca operasi elektif. ${ }^{11}$

Pada penelitian ini didapatkan peningkatan yang bermakna dari kadar CRP pasca operasi pada kedua kelompok. Dan juga didapatkan perbedaan bermakna pada kadar CRP pasca operasi antara kelompok kontrol dan 
kelompok perlakuan, di mana didapatkan kadar CRP pascaoperasi pada kelompok yang diberikan minuman karbohidrat dan protein whey praoperasi lebih rendah secara bermakna dibandingkan kelompok kontrol.

Adanya perbedaan yang bermakna dalam peningkatan nilai $C R P$ pra operasi dan pasca operasi antara kelompok kontrol dan kelompok perlakuan menunjukkan bahwa terjadi reaksi inflamasi akut yang lebih kecil pada kelompok yang mendapatkan minuman karbohidrat dan protein whey dibandingkan kelompok kontrol. Hal ini membuktikan bahwa pemberian minuman karbohidrat dan protein whey pra operasi dapat menurunkan respon inflamasi fase akut yang terjadi, yang tergambar dari peningkatan kadar $C R P$ pasca operasi yang lebih rendah pada kelompok perlakuan dibandingkan dengan kelompok kontrol.

$C R P$ merupakan protein yang diperlukan untuk mengatasi kerusakan jaringan dan infeksi. Protein ini juga bisa meningkat pada infeksi kronik, hipertensi, merokok, stroke, penyakit pembuluh darah dan arthritis rheumathoid. Dalam keadaan normal kadar $C R P$ di dalam darah $<5 \mathrm{mg} / \mathrm{L}$, pada respon fase akut kadarnyadapat meningkat 30 kali lipat dari nilai normalsehingga pemeriksaan CRP lebih sensitif dan lebih spesifik dibandingkan pemeriksaan laju endap darah (LED). Pada prinsipnya peningkatan kadar CRP terjadi pada kerusakan jaringan, inflamasi dan infeksi. ${ }^{12,13}$ Pada penelitian ini, semua subjek penelitian sudah dipilih dengan kriteria inklusi dan eksklusi sehingga faktor yang menyebabkan peningkatan $C R P$ selain inflamasi akut, dapat disingkirkan.

Pada penelitian ini diberikan minuman yang mengandung karbohidrat dan protein whey (peptamen) $400 \mathrm{ml}$ pada malam dan $200 \mathrm{ml}$ pada 4 jam pra operasi pada kelompok perlakuan. Sedangkan kelompok kontrol mendapatkan air putih dengan jumlah dan jam pemberian yang sama dengan ke- 
lompok perlakuan.Tidak ada kejadian aspirasi pada kedua kelompok atas pemberian minuman ini.Hal ini diperkirakan karena minuman yang diberikan sudah melewati masa pengosongan di lambung. Sesuai penelitian yang dilakukan Trans (2009) yang memberikan minuman karbohidrat oral praoperasi yang mengandung 12,5\% karbohidrat, $50 \mathrm{kkal} / 100 \mathrm{~mL}$ sebanyak $800 \mathrm{~mL}$ pada malam sebelum operasi dan $400 \mathrm{~mL}$ pada pagi hari sebelum operasi. Pengosongan lambung sudah terjadi dalam waktu 90 menit. Tidak ditemukan komplikasi aspirasi pada seluruh sampel. ${ }^{14}$

\section{DAFTAR PUSTAKA}

1. Ljungqvist $\mathrm{O}$. To fast or not to fast? Metabolic preparation for elective surgery. Scandinavian Journal of Nutrition 2004 ; 48 :77-82

2. Lauwick SM, Kaba A, Maweja S, Hamoir EE, Joris JL. Effects of oral preoperative carbohydrate on early post operative outcome after thyroidectomy. Acta Anaesth Belg 2009; $60: 67-73$

3. Ljunggren S, Hahn RG. Oral nutrition or water loading before hip replacement surgery. Ljunggren and Hahn trials $2012 ; 13$ : 97

4. Ljunggren S, Hahn RG, Nystrom T.
Insulin sensitivity and beta cell function after carbohydrate oral loading in hip replacement surgery. Clinical Nutrition 2014 ; 33: 392 -8

5. Dung H, Chai J. The effects and mechanisme of insulin on systemic inflamatory response and immune cells in severe trauma, burn injury and sepsis. International Immunopharmacology 2009; 9 : 1251 59

6. Desborough JP. The stress response to trauma and surgery. British Journal of Anaesthesia $2000 ; 85: 109-17$

7. Black S, Kushner I, Samols D. Creactive protein. Journal of Biological Chemistry 2004; 279: 48487490

8. Eklund CM. Proinflamatory cytokines in CRP baseline regulation. Adv clin chem 2009; 48: 111- 36

9. Raudah,Kurniasih E, Helmi, Dasriani N. Pemanfaatan pati gadung sebagai bahan baku pembuatan maltodextrin melalui hidrolisa enzimatis. SNYube 2013: 213-18

10. Awad S, Teodusio DC, Macdonald IA, Lobo DN . Short term starvation and mithocondrial dysfunction - A possible mechanism leading to postoperative insulin resistance. Clinical Nutrition 2009 ; 28 : 497-509

11. Perrone F, Filho ACS, Adorno IF, Anabuki NT, . Effects of pre operative feeding with whey protein plus 
carbohydrate drinks on the acute phase response and insulin resistance. A randomized trial. Nutrition Journal $2014 ; 10$

12. Easton R, Balogh ZJ . Perioperative changes in serum immune markers after trauma. International Care Injured $2014 ; 45: 934-41$

13. $\mathrm{Du}$ Clos TW. Function of CReactive Protein. Ann Med 2000 ; $32: 274-8$

14. Yilmaz N, Cekmen N, Bilgin F, Erten E, Ozhan MO, Cosar a. Pre operative carbohydrate nutrition reduces post operative nausea and vomiting compared to preoperative fasting. J Res Med Sci 2013; 18: 827 $-32$ 